International Review of Research in Open and Distributed Learning Volume 18, Number 5

August - 2017

\title{
Investigating Students' Perceptions of Motivating Factors of Online Class Discussions
}

Joohi Lee and Lesisa Martin

University of Texas at Arlington

\begin{abstract}
One of the goals of teacher education is to prepare our citizens to communicate in a variety of ways. In our present society, communication using digital media has become essential. Although online discussions are a common component of many online courses, engaging students in online discussions has been a challenge. This study queried 86 educators in a math/science teacher education graduate program to examine their perceptions on the factors that motivate them to participate in online discussions.

The results revealed a pragmatic outlook on online education. In terms of intrinsic versus extrinsic motivation, the participants' main motivation to participate in online class discussions was extrinsic (85.88\%), specifically so that they could earn an acceptable participation grade. With regards to discussion grouping formats, they preferred small group discussions (81\%) which could facilitate their ability to develop rapport with a small group of fellow classmates over whole class discussion (38.83\%). With respect to discussion facilitation, they focused on the practical need to have the instructor to answer their questions about course assignments (67.06\%) over online open discussion without a given topic (35.72\%). Next, when asked about discussion question types based on Bloom's taxonomy, their strongest preference reflected a desire for application (89.54\%) questions which would facilitate their ability to use theories discussed in class in their daily work as educators. Through collaboration with twenty-first-century learners, online education can use data-driven decision making to help transform online discussion from being the least desirable component of online courses to a more relevant, instructional medium.
\end{abstract}

Keywords: online discussion, engaging factors, online education, teacher education, graduate students

\section{Introduction}

While higher education in the United States has traditionally focused on face-to-face instruction, a growing body of research has been devoted to online education. About 6.7 million college and university students 
took at least one online course in 2012, and this number increased to 7.1 million in 2013 (Allen \& Seaman, 2013). This reflects current trends showing the rapid growth of online enrollment in higher education. Many universities and colleges have been expanding online education or considering offering online education courses or programs (Ambient Insight Research, 2009; Christensen, Horn, Caldera, \& Soares, 2011; Nagel, 2010). Considering the current growth of online learning, the major concern in the field of online education is how to provide students with a quality online education experience. In response to this issue, it has become critical to closely examine components of online education such as online course design and online course discussion.

Peer interactions and communication in social and cultural contexts have long been considered to be highly effective in learning (Berk \& Winsler, 1995). Online interactions and discussions among students and instructors have become a significant part of online coursework ( $\mathrm{Du} \& \mathrm{Xu}, 2010$; Hall, 2015) because interaction, collaboration, communication, and discussions are seen as key elements for making online learning meaningful to students (Russell, Kleiman, Carey, \& Douglas, 2009). In the field of teacher education, active online communication among citizens is considered critical because a goal of teacher education is to prepare educators to efficiently communicate with students and the public in a variety of media including digital (Hew \& Cheung, 2012).

Online education offers learners a variety of benefits. The online format allows learners who may not be able to attend face-to-face classes due to work or family obligations the opportunity to pursue a degree online via asynchronous coursework (Hartnett, 2016). Through the asynchronous format option, class discussion is not limited to the class period or office hours; the 24 hours/7 days a week format gives teacher candidates an expanded, flexible forum for networking, discussing, and debating class content (Bonk \& Khoo, 2014). The online class discussion format offers opportunities for active participation and can provide learners time to think and to compose their thoughts before sharing their views online (Bonk \& Khoo, 2014; Hew \& Cheung, 2012). However, some learners have expressed dissatisfaction regarding online class discussions (Lee, 2014; Gerbic, 2006; Hartnett, 2016; Hew \& Cheung, 2012; Pisutova-Gerber \& Malovicova, 2009). In order to build a more engaging environment for online discussion that promotes active student participation, it is necessary to identify which characteristics promote learner engagement during online course discussions.

\section{Theoretical Frameworks}

Two key components that influence active participation during online class discussions are the instructor and the learners. The instructor may use the Community of Inquiry (COI) (Garrison, Anderson, \& Archer, 2000) to design and implement the course. However, the interactions between the Community of Inquiry and intrinsic/extrinsic motivation can come into play when learners decide how they will respond to the course design and implementation based on their intrinsic and extrinsic motivations (Deci, Cascio, \& Krusell, 1975; Deci \& Ryan, 1985; Ryan \& Deci, 2000). By directly querying the participants, we sought to see how the interplay between their response to the Community of Inquiry and intrinsic/extrinsic motivation can be used to facilitate learners' interest in online course discussions. The study included two 
conceptual frameworks: Community of Inquiry and intrinsic/extrinsic motivation (See Figure 1 for the figural theoretical framework of this study).

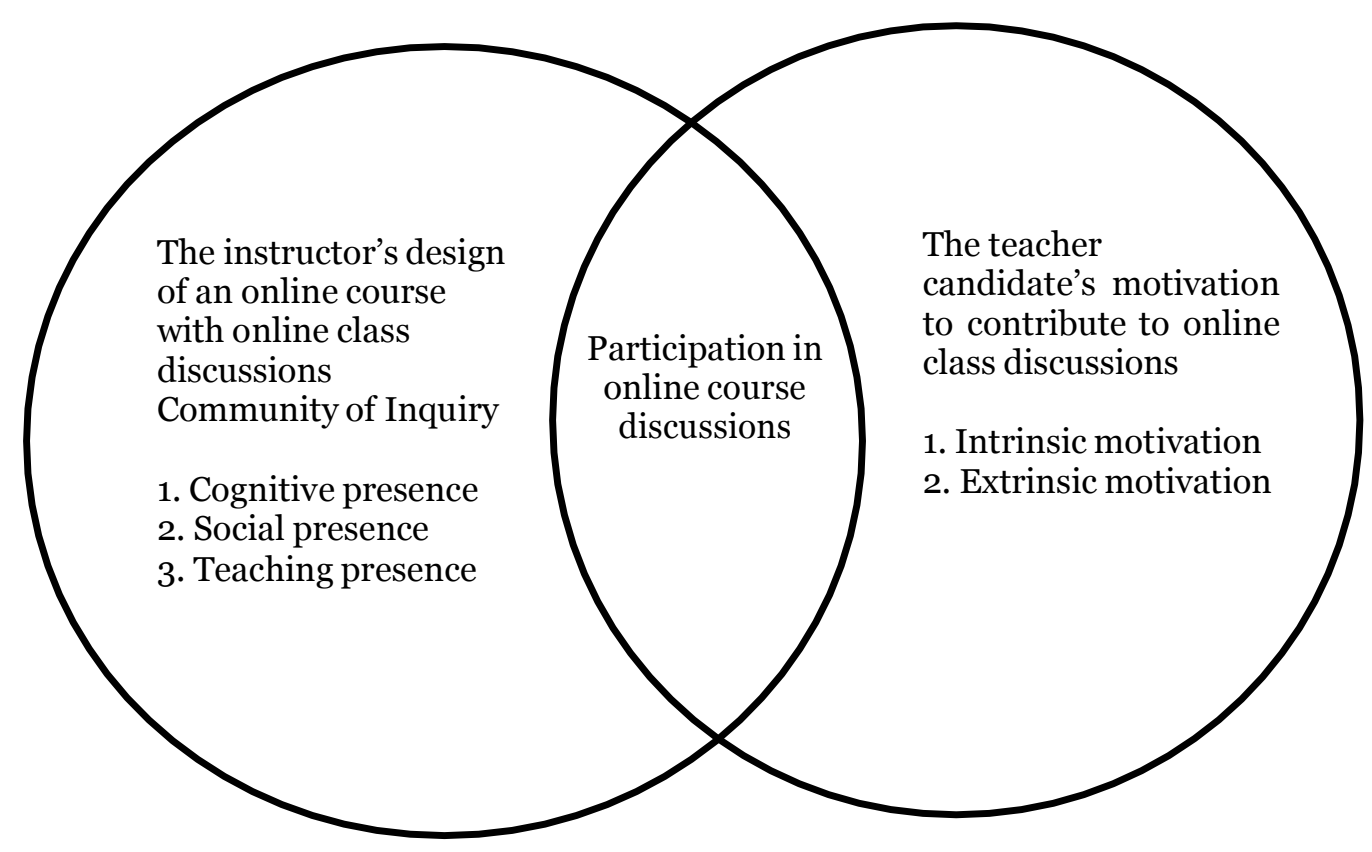

Figure 1. The interrelationship between the conceptual frameworks.

\section{Community of Inquiry}

The Community of Inquiry model has been commonly used to investigate three types of presence: cognitive presence, social presence, and teaching presence (Arbaugh et al., 2008; Garrison et al., 2000). Cognitive presence involves types of pedagogical activities resulting in student learning processes and outcomes (Garrison, Anderson, \& Archer, 2001). Social presence in online learning includes creating a sense of a supportive virtual community and developing a trusting and safe environment for peers and instructors (Meyer, 2014). Social presence involves a feeling of connection to other classmates, which often functions as a factor for motivating student learning (Sweet \& Michaelson, 2012). Finally, teaching presence includes instructional design and organization, facilitation, direct instruction, and the managerial responsibilities involved in the course. Teaching presence is the "design, facilitation and direction of cognitive and social processes for the purpose of realizing personally meaningful and educationally worthwhile learning outcomes" (Garrison, 2007, p. 24). Some examples of teaching presence associated particularly with discussions include grouping students for online discussion (Lee, 2014; Garrison et al., 2001), facilitating discussion (Russell et al., 2009), and submitting guiding or focal questions or content to guide the discussions (Rettig, 2013).

\section{Intrinsic and Extrinsic Motivation}

Learner motivation is viewed as crucial to the learners' success in an online coursework environment because it can influence students' decisions to stay in or drop out of a course (Bonk \& Khoo, 2014), their 
degree of engagement in the course, the quality of the work, and their level of achievement in the online course (Hartnett, 2016). Intrinsic motivation refers to "doing something because it is inherently interesting or enjoyable" (Ryan \& Deci, 2000, p. 55) while extrinsic motivation refers to "doing something because it produces a separable outcome" (Ryan \& Deci, 2000, p. 55). Sometimes, these motivators interact with each other to promote or undermine one's intrinsic motivations in social contexts (Ryan \& Deci, 2000). When students are intrinsically motivated, learning outcomes can be maximized. On the other hand, extrinsic motivation sometimes tends to undermine intrinsic motivation based on autonomy in one's own social context. Students tend to be intrinsically motivated when they feel in control or have choice, possess high perceived competence, receive informational rewards, and the activity is task-involved (Mandigo \& Holt, 2000). When a student feels controlled by external factors, the level of intrinsic motivation is undermined.

\section{Literature Review}

In a study evaluating different components of online courses, United States educators in an online graduate teacher education program rated online discussion as the least useful component in online courses (Lee, 2014). Learners' disinterest for online course discussion is not an isolated issue; both in the United States and overseas, learners have shown distaste for online course discussions. Fung (2004) documented the interests in online discussion of students enrolled in teacher education programs in Hong Kong and found an overall lack of student interest in online class discussions. According to Fung (2004), students wanted to spend their time completing the course readings rather than discussing the course material online with their classmates. Winograd (2000) found a similar tendency among business majors in the United Stateswho reported that online discussions are a waste of time.

Elements of resistance were also present in two more recent studies set in New Zealand studies. Naughton, Smeed, and Roder (2011) investigated the interests in online discussions of full time elementary school teachers who were taking an online course. Their participants reported that their goal was to complete their course assignments and their online discussion posts in the most expedient manner possible and to make the minimum number of posts. Hartnett (2016) reported a similar finding: teacher candidates enrolled in an ndergraduate class expressed a lack of interest in online discussions when they were required to participate in online discussions as part of a group project.

\section{Cognitive Presence}

Learners in online courses tend to be older students with work responsibilities and family responsibilities (Brooks \& Bippus, 2012; Romero \& Barberà, 2011). When they are working a full time job, dealing with family commitments, and taking online classes, time can be a scarce commodity. Some individuals overcome their personal circumstances and graduate with their degree (Meyer, 2014). However, a lack of time due to variables such as work commitments or family commitments leaves them with less time to participate in online discussions (Fung, 2004; Gerbic, 2006; Hammond, 1999; Hew \& Cheung, 2010a; Jeong \& Frasier, 2008; Norton \& Hathaway, 2008; Rollag, 2010), can negatively impact their ability to 
learn the coursework (Fisher, 2010; Meyer, 2014), and can lead them to withdraw from online courses (Bonk \& Khoo, 2014; Hartnett, 2016).

\section{Social Presence and Teaching Presence}

Feeling a sense of connection to other classmates can be a valuable resource for motivating students, especially in larger classes (Sweet \& Michaelson, 2012). While some students enjoy interacting with fellow classmates, creating friendships with them, and helping them understand the class content, time limitations can negatively impact students' ability to participate in the social aspect of an online course.

Discussion grouping. Collaborative discussions can promote critical thinking skills and the long-term retention of information (Hew \& Cheung, 2012) as well as help students focus on in-depth discussion (Qui, Hewitt, \& Brett, 2014). To cultivate a social presence in online classes, instructors have a variety of options. Whole class instruction provides an opportunity for all class members to interact, but in large classes, trying to read a large number of postings by a large number of classmates can result in cognitive overload (Hew \& Cheung, 2010b; Rollag, 2010). In addition, Nonnecke and Preece (2002) and Hew and Cheung (2010b) note that as the group size increases, individuals feel less of a need to contribute to the conversation.

An alternative is small group discussion. However, there are different opinions about how large or how small the group should be. Schellens and Valcke (2006) found that students in smaller online discussion groups of 8 to 10 displayed higher levels of knowledge construction than students in larger online discussion groups of 15 to 18 students. Hew and Cheung (2010b) concluded that for online discussions, the ideal group size is ten students per group. Sweet and Michaelson (2012) noted that many cooperative learning strategies recommend four students per group, but for Team Based Learning, they recommend five to seven students in a group. Meanwhile, with the Think, Pair, Share approach, each student individually reflects on a question, locates a partner, and then shares their thoughts with the partner.

Discussion facilitation. After deciding the type of grouping to be used in an online course, instructors face decisions on whether to have the instructor or students lead the online class discussions. However, the research on having the course instructor lead the online discussion has yielded mixed results (Hew \& Cheung, 2012). Dykman and Davis (2008) as well as Gilmore and Warren (2007) emphasized the need for the instructor to interact in online course discussions. Furthermore, Xie, DeBacker, and Ferguson (2006) and Rollag (2010) noted that when the instructor displays little or no involvement in the online class discussions, the students feel ignored and are less willing to contribute. However, Zhu (2006) cautions that if the instructor offers his or her expert opinion to every student post, discussion can be stifled, and An, Shin, and Lim (2009) found that when the instructor kept his or her involvement in online discussion to a minimum, the students more freely discussed their points of view. Furthermore, Mazzolini and Maddison (2007) reported that as the instructor increased his or her participation in online discussions, students posted less frequently and posted shorter discussion threads.

An alternative is to have a fellow classmate facilitate the online discussion. Prior studies have shown that students feel more comfortable discussing their ideas and challenging their fellow classmates' ideas in an online course discussion facilitated by a fellow classmate than the course instructor (Correia \& Davis, 2007; 
Rourke \& Anderson, 2002). In addition, Rourke and Anderson (2002) found that students preferred having a fellow classmate lead the online discussions over having the instructor lead the course discussions, and they posted more messages each week when the classmate facilitated the online discussion than when the instructor did so. Seo (2007) found that, compared to instructor-led online discussions, peer-led online discussions led to more posts and more substantive posts. Moreover, Tagg (1994) found that when a fellow classmate facilitated the class' online course discussion, students better understood the content and participated more. However, Tagg notes that the instructor would need to provide guidance to the peer facilitator; in addition, the instructor would be better suited to address students who make irrelevant comments or too lengthy comments.

Levels of questioning. Related to grouping formats and discussion facilitation is a decision to emphasize lower levels or higher levels of questions based on Bloom's taxonomy. While some students wish to engage in high level thinking, others reject this type of learning activity (Hall, 2015; Meyer, 2014). Stein, Wanstreet, Slagle, Trinko, and Lutz (2013) found that the use of coaching by the instructor and feedback from the instructor increased high-level thinking in online class discussions. Furthermore, Umbach and Wawrzynski (2005) concluded that when the course included activities that promoted higher order thinking skills, students were more engaged during class. However, in a synthesis of the critical thinking literature with online classes, Maurino (2006-2007) found that higher level thinking during online class discussions is uncommon.

\section{Intrinsic and Extrinsic Motivation}

Barkely (2010) argues that a combination of motivation and active learning can contribute to increased student engagement. However, learners participate in online coursework for a variety of reasons. Some learners are intrinsically motivated, and they enjoy learning for the sake of learning. Others are extrinsically motivated by external reinforcers such as grades, a degree, or an opportunity to receive a pay raise after they obtain their degree. In the online classroom, extrinsic motivation can impact learners' approach to their coursework. For example, Yeh and Buskirk (2005) found that students were more focused on obtaining online discussion participation points than in exchanging ideas with fellow classmates. Furthermore, Pena-Shaft and Nicholls (2004) observed that after students had met the minimum number for the required postings, they ceased their contributions to the course's weekly online discussion.

Taking previous studies regarding student dissatisfaction with online discussion into account, this study directly queried the students to better understand their perspectives about online course discussions. The study explored one major research question. What characteristics associated with intrinsic/extrinsic motivation and Community of Inquiry do students view as engaging factors in online discussions?

\section{Methodology}

A cross-sectional study has been shown to be an efficient research method to investigate current behaviours, attitudes, and perspectives of participants (Gay, Mills, \& Airasian, 2009). In this study, we conducted a 
cross-sectional study with graduate students who were enrolled in an online course in spring 2014. Specifically, this study was conducted at an urban public university in the southwestern United States with math/science graduate students who were pursuing a Master's degree. The 36-credit-hour graduate degree program includes 12 five-week asynchronous online courses that students take on their own schedule. Each course includes five modules and mandatory online discussions. A total of 86 graduate students voluntarily participated in the study. Demographic data on the participants is presented in the following table (See Table 1).

Table 1

Demographic Data

\begin{tabular}{|c|c|c|}
\hline Demographic & Percentage & $\begin{array}{c}\text { Total } \\
(N)\end{array}$ \\
\hline \multicolumn{3}{|l|}{ Gender } \\
\hline Female & $87.21 \%$ & 75 \\
\hline Male & $12.19 \%$ & 11 \\
\hline \multicolumn{3}{|l|}{ Race/ethnicity } \\
\hline White & $73.26 \%$ & 63 \\
\hline Hispanic & $10.47 \%$ & 6 \\
\hline Asian & $5.81 \%$ & 5 \\
\hline African American & $1.16 \%$ & 1 \\
\hline American Indian/Alaska Native & $1.16 \%$ & 1 \\
\hline \multicolumn{3}{|l|}{ Age } \\
\hline 18-25 years & $4.65 \%$ & 4 \\
\hline 26-30 years & $16.28 \%$ & 14 \\
\hline 31-35 years & $12.79 \%$ & 11 \\
\hline $36-40$ years & $15.12 \%$ & 13 \\
\hline 41-45 years & $13.95 \%$ & 12 \\
\hline $45-50$ years & $13.95 \%$ & 12 \\
\hline 51-55 years & $15.12 \%$ & 13 \\
\hline 56-60 years & $4.65 \%$ & 4 \\
\hline 61-65 years & $2.30 \%$ & 2 \\
\hline $66+$ years & $1.16 \%$ & 1 \\
\hline \multicolumn{3}{|l|}{ Educational setting } \\
\hline $\begin{array}{l}\text { All-level education } \\
\text { (Kindergarten through grade 12) }\end{array}$ & $54.65 \%$ & 47 \\
\hline Elementary education & $19.77 \%$ & 17 \\
\hline Middle school education & $6.98 \%$ & 6 \\
\hline High school education & $18.60 \%$ & 16 \\
\hline
\end{tabular}

\section{Instrumentation}

For the purpose of this study, we developed a total of 23 survey questionnaire items by reviewing existing literature on intrinsic and extrinsic motivators associated with cognitive, social, and teaching presences. Respondents answered each item using a 5-point Likert scale ranging from $1=$ strongly disagree to $5=$ strongly agree. The survey items used in this study are listed in the Appendix. 
Content validity. Content validity evaluates the degree to which the survey items represent the content area that the survey seeks to measure (Leedy \& Ormrod, 2016). To increase content validity, the authors used core concepts from Community of Inquiry (social, cognitive, and teaching presence) as well as items related to intrinsic and extrinsic motivation in the survey to investigate the engaging factors of online discussions. In order to assess content validity, the survey items were reviewed by two professors in the field of education, and the items were revised accordingly. After assessing content validity and revising the survey items, the authors conducted a pilot study to measure the reliability of the survey instrument. Once we developed the survey items, we ran Exploratory Factor Analysis to analyze factor loadings on the 23 items. We eliminated the items with low factor loadings: building learning community, instructor only answering to student questions, obtaining and providing information, and completing course work.

Exploratory factor analysis. In order to examine whether inter-item correlation exists among the survey questionnaire items, we conducted exploratory factor analysis with the 86 students' survey responses. The purpose of exploratory factor analysis is to reduce "the dimensionality of the original space and to give an interpretation to the new space, spanned by a reduced number of new dimensions which aresupposed to underlie the old ones" (Rietveld \& Van Hout, 1993, p. 253). We used a scree plot to define the number of components and obtained five principal components from the survey items. We also utilized principal component analysis with the Oblimin with Kaiser normalization rotation method by eliminating components with loadings that were lower than .3 (see Table 2 for Factor Loadings). We used the Oblimin rotation method since it allows factors to have correlated one another (Osborne, 2015).

Table 2

Factor Loadings Using Principal Component Analysis

\begin{tabular}{|c|c|c|c|c|c|c|c|c|}
\hline & \multicolumn{8}{|c|}{ Component } \\
\hline & 1 & 2 & 3 & 4 & 5 & 6 & 7 & 8 \\
\hline Helping others & .873 & & & & & -.218 & & .170 \\
\hline $\begin{array}{l}\text { Practicing open } \\
\text { interactions }\end{array}$ & .816 & & & & .231 & & & -.149 \\
\hline Increasing knowledge & .793 & & & -.105 & -.277 & & & -.252 \\
\hline Building friendships & .706 & & & & & & & \\
\hline $\begin{array}{l}\text { Building learning } \\
\text { community }\end{array}$ & .259 & .284 & & & & .354 & & \\
\hline $\begin{array}{l}\text { Question thread- } \\
\text { analysis }\end{array}$ & & .831 & & & & & & \\
\hline $\begin{array}{l}\text { Question thread- } \\
\text { synthesis }\end{array}$ & & .797 & -.188 & & & & & \\
\hline $\begin{array}{l}\text { Question thread- } \\
\text { application }\end{array}$ & & 692 & .213 & & -.416 & -.298 & & \\
\hline
\end{tabular}




\begin{tabular}{|c|c|c|c|c|c|c|c|c|}
\hline $\begin{array}{l}\text { Question thread- } \\
\text { judgment }\end{array}$ & & .520 & .227 & .313 & .342 & .320 & & \\
\hline $\begin{array}{l}\text { Question thread- } \\
\text { comprehension }\end{array}$ & & .113 & .885 & & -.118 & & & \\
\hline $\begin{array}{l}\text { Questioning thread- } \\
\text { knowledge }\end{array}$ & & -.105 & .829 & .130 & .209 & & & \\
\hline Get through course & & & -.185 & .831 & -.107 & & & \\
\hline Get acceptable grade & -.176 & & .174 & .778 & & -.109 & .179 & \\
\hline $\begin{array}{l}\text { Discussion-facilitator } \\
\text { class member }\end{array}$ & .119 & & & & .773 & -.334 & -.184 & .213 \\
\hline $\begin{array}{l}\text { Grouping preference } \\
\text { think-pair-share }\end{array}$ & & .113 & & -.177 & .317 & .101 & .316 & -.273 \\
\hline $\begin{array}{l}\text { Discussion-facilitator } \\
\text { teaching assistant }\end{array}$ & & .225 & & & .641 & -.780 & & -.158 \\
\hline $\begin{array}{l}\text { Discussion-facilitator } \\
\text { instructor }\end{array}$ & & .143 & & & .520 & -.546 & & \\
\hline $\begin{array}{l}\text { Grouping preference- } \\
\text { small groups }\end{array}$ & & .132 & & & .352 & & & -.101 \\
\hline $\begin{array}{l}\text { Grouping preference- } \\
\text { whole class }\end{array}$ & .137 & & .215 & -.148 & .397 & -.157 & -.631 & -.121 \\
\hline $\begin{array}{l}\text { Question open } \\
\text { discussion }\end{array}$ & -.136 & .106 & & & .210 & & -.602 & \\
\hline $\begin{array}{l}\text { Discussion-instructor } \\
\text { only questions }\end{array}$ & .160 & -.287 & .245 & -.138 & & -.230 & .351 & .342 \\
\hline $\begin{array}{l}\text { Obtaining \& providing } \\
\text { information }\end{array}$ & .136 & .171 & & .242 & & .193 & & .720 \\
\hline $\begin{array}{l}\text { Completing course } \\
\text { work }\end{array}$ & .253 & & & .306 & & & & -.602 \\
\hline
\end{tabular}

Rotation Method: Oblimin with Kaiser Normalization.

The five principal components from highest to lowest loading factor are as follows: 1) intrinsic motivators associated with social and cognitive presences, 2) types of questions higher than comprehension level, 3) types of questions associated with comprehension and knowledge, 4) extrinsic motivators associated with cognitive presence, and 5) facilitator's roles and grouping.

\section{Data Collection and Analysis Procedure}

The survey was administered via SurveyMonkey.com. The data were analyzed for each communication medium (social, cognitive, and teaching presence) using descriptive statistics. 


\section{Results}

Tables 3 through 6 present the participants' perceptions about the factors that motivate them to participate in online discussions. The participants' responses are presented below with the categories of intrinsic and extrinsic motivators associated with cognitive and social presences (Table 3 ) and teaching presence (Tables 4,5 , and 6).

\section{Intrinsic Motivators Associated with Cognitive Presence and Social Presence}

The results for questions related to cognitive and social presences are shown in the following table (See Table 3).

Table 3

Extrinsic and Intrinsic Motivators Associated with Cognitive and Social Presences

\begin{tabular}{|c|c|c|c|c|c|c|c|}
\hline Motivator & Question Item & $\overline{\text { SA }}$ & $\mathrm{A}$ & $\mathrm{N}$ & $\mathrm{D}$ & SDA & $\begin{array}{c}\text { Total } \\
(N)\end{array}$ \\
\hline \multirow[t]{4}{*}{ Intrinsic } & To help classmates & $\begin{array}{l}25.00 \% \\
(n=21)\end{array}$ & $\begin{array}{l}47.62 \% \\
(n=40)\end{array}$ & $\begin{array}{l}16.67 \% \\
(n=14)\end{array}$ & $\begin{array}{l}8.33 \% \\
(n=7)\end{array}$ & $\begin{array}{l}2.38 \% \\
(n=2)\end{array}$ & 84 \\
\hline & $\begin{array}{l}\text { To participate in } \\
\text { open interactions }\end{array}$ & $\begin{array}{l}26.51 \% \\
(n=22)\end{array}$ & $\begin{array}{l}34.94 \% \\
(n=29)\end{array}$ & $\begin{array}{l}24.10 \% \\
(n=20)\end{array}$ & $\begin{array}{l}10.84 \% \\
(n=9)\end{array}$ & $\begin{array}{l}3.61 \% \\
(n=3)\end{array}$ & 83 \\
\hline & $\begin{array}{l}\text { To increase } \\
\text { knowledge of } \\
\text { subject/materials }\end{array}$ & $\begin{array}{l}38.83 \% \\
(n=33)\end{array}$ & $\begin{array}{l}48.24 \% \\
(n=41)\end{array}$ & $\begin{array}{l}4.71 \% \\
(n=4)\end{array}$ & $\begin{array}{l}5.88 \% \\
(n=5)\end{array}$ & $\begin{array}{l}2.35 \% \\
(n=2)\end{array}$ & 85 \\
\hline & To build friendships & $\begin{array}{l}10.71 \% \\
(n=9)\end{array}$ & $\begin{array}{l}19.05 \% \\
(n=16)\end{array}$ & $\begin{array}{l}39.29 \% \\
(n=33)\end{array}$ & $\begin{array}{l}23.81 \% \\
(n=20)\end{array}$ & $\begin{array}{l}7.14 \% \\
(n=6)\end{array}$ & 84 \\
\hline \multirow[t]{2}{*}{ Extrinsic } & $\begin{array}{l}\text { To get through the } \\
\text { course }\end{array}$ & $\begin{array}{l}65.48 \% \\
(n=55)\end{array}$ & $\begin{array}{l}32.14 \% \\
(n=27)\end{array}$ & $\begin{array}{l}1.19 \% \\
(n=1)\end{array}$ & $\begin{array}{l}1.19 \% \\
(n=1)\end{array}$ & $\begin{array}{l}0.00 \% \\
(n=0)\end{array}$ & 84 \\
\hline & $\begin{array}{l}\text { To earn acceptable } \\
\text { participation grade }\end{array}$ & $\begin{array}{l}85.88 \% \\
(n=73)\end{array}$ & $\begin{array}{l}12.94 \% \\
(n=11)\end{array}$ & $\begin{array}{l}1.18 \% \\
(n=1)\end{array}$ & $\begin{array}{l}0.00 \% \\
(n=0)\end{array}$ & $\begin{array}{l}0.00 \% \\
(n=0)\end{array}$ & 85 \\
\hline
\end{tabular}

Note. $S A=$ Strongly Agree; $A=$ Agree; $N$ = Neither agree nor disagree; $D=$ Disagree; $S D A=$ Strongly Disagree

When percentages for "agree" and strongly agree" are combined, the data show that participants were more motivated by extrinsic motivators such as earning participation points (98.82\%) and getting through the course (97.62\%) than on increasing their subject knowledge (87.07\%). When percentages for "agree" and strongly agree" are combined, participants were more interested in helping classmates (72.62\%) or having open interactions (61.45\%) than in forming friendships with classmates (29.76\%).

\section{Teaching Presence}

Items associated with teaching presence in this study include grouping, facilitation of online discussion, and types of questions. 
Discussion grouping. Table 4 presents students' perception of the types of grouping that motivate their participation in discussion more. About $81 \%$ of participants (combined percentage of "agree" [24.71] and "strongly agree" [56.47\%]) preferred discussions with a small group than either whole group discussion (38.83\%) or think/pair/share discussion (37.21\%).

Table 4

Motivating Factors Associated with Teaching Presence - Discussion Grouping

\begin{tabular}{|c|c|c|c|c|c|c|}
\hline \multicolumn{7}{|c|}{ Teaching Presence } \\
\hline Question Item & SA & $\mathrm{A}$ & $\mathrm{N}$ & $\mathrm{D}$ & SDA & $\begin{array}{c}\text { Total } \\
(\mathrm{N})\end{array}$ \\
\hline Small group & $\begin{array}{l}56.47 \% \\
(n=48)\end{array}$ & $\begin{array}{l}24 \cdot 71 \% \\
(n=21)\end{array}$ & $\begin{array}{c}9.41 \% \\
(n=8)\end{array}$ & $\begin{array}{c}5.88 \% \\
(n=5)\end{array}$ & $\begin{array}{c}3.53 \% \\
(n=3)\end{array}$ & 85 \\
\hline Whole class discussion & $\begin{array}{l}14.12 \% \\
(n=12)\end{array}$ & $\begin{array}{l}24.71 \% \\
(n=21)\end{array}$ & $\begin{array}{l}24.71 \% \\
(n=21)\end{array}$ & $\begin{array}{l}24.71 \% \\
(n=21)\end{array}$ & $\begin{array}{l}11.76 \% \\
(n=10)\end{array}$ & 85 \\
\hline Think/Pair/Share* & $\begin{array}{l}13.95 \% \\
(n=12)\end{array}$ & $\begin{array}{l}23.26 \\
(n=20)\end{array}$ & $\begin{array}{l}27.91 \% \\
(n=24)\end{array}$ & $\begin{array}{l}27.91 \% \\
(n=24)\end{array}$ & $\begin{array}{l}12.79 \% \\
(n=11)\end{array}$ & 86 \\
\hline
\end{tabular}

Note. $S A=$ Strongly Agree; $A=$ Agree $; N=$ Neither agree nor disagree; $D=$ Disagree; $S D A=$ Strongly Disagree

*In the Think/Pair/Share method, the students locate a partner, think about the given discussion questions, and chat about it with their partner. Then, the whole class has a discussion.

Discussion facilitation. Table 5 shows the results of engaging factors for teaching presence focusing on discussion facilitation. When responses for "agree" and "strongly agree" were combined, less preferable alternatives were to have the Teaching Assistant facilitate the online discussions (62.35\%), to have the instructor facilitate the online discussions (58.83\%), or to have a designated classmate facilitate the discussions (15.29\%).

Table 5

Engaging Factors Associated with Teaching Presence - Discussion Facilitation

\begin{tabular}{|c|c|c|c|c|c|c|}
\hline \multicolumn{7}{|c|}{ Teaching Presence } \\
\hline Question Item & SA & $\mathrm{A}$ & $\mathrm{N}$ & $\overline{\mathrm{D}}$ & SDA & $\begin{array}{c}\text { Total } \\
(\mathrm{N})\end{array}$ \\
\hline $\begin{array}{l}\text { Instructor facilitates } \\
\text { discussions }\end{array}$ & $\begin{array}{l}24.71 \% \\
(n=21)\end{array}$ & $\begin{array}{l}34.12 \% \\
(n=29)\end{array}$ & $\begin{array}{l}30.59 \% \\
(n=26)\end{array}$ & $\begin{array}{c}9.41 \% \\
(n=8)\end{array}$ & $\begin{array}{l}1.18 \% \\
(n=1)\end{array}$ & 85 \\
\hline $\begin{array}{l}\text { Teaching Assistant } \\
\text { facilitates discussions }\end{array}$ & $\begin{array}{l}18.82 \% \\
(n=16)\end{array}$ & $\begin{array}{l}43.53 \% \\
(n=37)\end{array}$ & $\begin{array}{l}25.88 \% \\
(n=22)\end{array}$ & $\begin{array}{r}9.41 \% \\
(n=8)\end{array}$ & $\begin{array}{l}2.35 \% \\
(n=2)\end{array}$ & 85 \\
\hline $\begin{array}{l}\text { A designated class } \\
\text { member facilitates the } \\
\text { discussion }\end{array}$ & $\begin{array}{c}2.35 \% \\
(n=2)\end{array}$ & $\begin{array}{l}12.94 \% \\
(n=11)\end{array}$ & $\begin{array}{l}37.65 \% \\
(n=32)\end{array}$ & $\begin{array}{l}29.41 \% \\
(n=25)\end{array}$ & $\begin{array}{l}17.65 \% \\
(n=15)\end{array}$ & 85 \\
\hline
\end{tabular}

Note. SA = Strongly Agree; $A$ = Agree; $N$ = Neither agree nor disagree; $D=$ Disagree; $S D A=$ Strongly Disagree 
Discussion questions. Table 6 shows the results of engaging factors associated with teaching presence focusing on the types of discussion questions. After combining the percentages of "agree" and "strongly agree," the majority of participants preferred threaded discussion questions involving application (89.54\%) over analysis (78.83\%), synthesis (78.82\%), judgment (65.88\%), comprehension (61.62\%), or facts (54.11\%).

Table 6

Engaging Factors Associated with Teaching Presence - Discussion Questioning

\begin{tabular}{|c|c|c|c|c|c|c|c|}
\hline \multicolumn{8}{|c|}{ Teaching Presence } \\
\hline $\begin{array}{l}\text { Levels of } \\
\text { Questions }\end{array}$ & Question Item & $\overline{\mathrm{SA}}$ & A & $\mathrm{N}$ & $\bar{D}$ & SDA & $\begin{array}{c}\text { Total } \\
(\mathrm{N})\end{array}$ \\
\hline \multirow[t]{2}{*}{$\begin{array}{l}\text { Comprehension } \\
\text { Level }\end{array}$} & $\begin{array}{l}\text { Threaded } \\
\text { discussion based } \\
\text { on facts }\end{array}$ & $\begin{array}{l}11.76 \% \\
(n=10)\end{array}$ & $\begin{array}{l}42.35 \% \\
(n=36)\end{array}$ & $\begin{array}{l}21.18 \% \\
(n=18)\end{array}$ & $\begin{array}{l}16.47 \% \\
(n=14)\end{array}$ & $\begin{array}{l}8.24 \% \\
(n=7)\end{array}$ & 85 \\
\hline & $\begin{array}{l}\text { Threaded } \\
\text { discussion } \\
\text { requiring } \\
\text { comprehension }\end{array}$ & $\begin{array}{l}13.95 \% \\
(n=12)\end{array}$ & $\begin{array}{l}47.67 \% \\
(n=41)\end{array}$ & $\begin{array}{l}23.26 \% \\
(n=20)\end{array}$ & $\begin{array}{l}10.47 \% \\
(n=9)\end{array}$ & $\begin{array}{l}4.65 \% \\
(n=4)\end{array}$ & 86 \\
\hline \multirow[t]{4}{*}{$\begin{array}{l}\text { Higher than } \\
\text { Comprehension } \\
\text { Level }\end{array}$} & $\begin{array}{l}\text { Threaded } \\
\text { discussion } \\
\text { requiring } \\
\text { application }\end{array}$ & $\begin{array}{l}32.56 \% \\
(n=28)\end{array}$ & $\begin{array}{l}56.98 \% \\
(n=49)\end{array}$ & $\begin{array}{c}9.30 \% \\
(n=8)\end{array}$ & $\begin{array}{c}0.00 \% \\
(n=0)\end{array}$ & $\begin{array}{l}1.16 \% \\
(n=1)\end{array}$ & 86 \\
\hline & $\begin{array}{l}\text { Threaded } \\
\text { discussion } \\
\text { requiring analysis }\end{array}$ & $\begin{array}{l}24.71 \% \\
(n=21)\end{array}$ & $\begin{array}{l}54.12 \% \\
(n=46)\end{array}$ & $\begin{array}{l}14.12 \% \\
(n=12)\end{array}$ & $\begin{array}{c}5.88 \% \\
(n=5)\end{array}$ & $\begin{array}{l}1.18 \% \\
(n=1)\end{array}$ & 85 \\
\hline & $\begin{array}{l}\text { Threaded } \\
\text { discussion } \\
\text { requiring synthesis }\end{array}$ & $\begin{array}{l}31.76 \% \\
(n=27)\end{array}$ & $\begin{array}{l}47.06 \% \\
(n=40)\end{array}$ & $\begin{array}{l}15.29 \% \\
(n=13)\end{array}$ & $\begin{array}{r}4.71 \% \\
(n=4)\end{array}$ & $\begin{array}{l}1.18 \% \\
(n=1)\end{array}$ & 85 \\
\hline & $\begin{array}{l}\text { Threaded } \\
\text { discussion } \\
\text { requiring judgment }\end{array}$ & $\begin{array}{l}18.82 \% \\
(n=16)\end{array}$ & $\begin{array}{l}47.06 \% \\
(n=40)\end{array}$ & $\begin{array}{l}23.53 \% \\
(n=20)\end{array}$ & $\begin{array}{c}7.06 \% \\
(n=6)\end{array}$ & $\begin{array}{l}3.53 \% \\
(n=3)\end{array}$ & 85 \\
\hline
\end{tabular}

Note. $S A=$ Strongly Agree; $A=$ Agree; $N$ = Neither agree nor disagree; $D=$ Disagree; $S D A=$ Strongly Disagree 


\section{Discussion}

Interest in online education is growing, and the number of online classes offered in higher education has been increasing (An \& Frick, 2006; Christensen, et al., 2011; Nagel, 2010; Shea \& Bidjerano 2009). In Allen and Seaman's (2013) higher education survey of 2,820 higher education institutions, $86.5 \%$ of the institutions offered online courses and $62.4 \%$ offered completely online degree programs, and $32 \%$ of students reported that they are currently taking one or more online university courses (Allen \& Seaman, 2013).Yet, in prior studies, students felt that online discussion in online classes was irrelevant (Lee, 2014; Fung, 2004; Hartnett, 2016; Naughton, Smeed, \& Roder, 2011; Winograd, 2000). In response to this issue, we sought to learn teacher candidates' views on this issue and their perspectives on ways to address it. Through their responses, they emphasized the need for a pragmatic approach to online learning and online discussion.

\section{Cognitive and Social Presences}

When individuals undertake coursework, they may be motivated by internal forces such as the desire to learn new information or by external forces such as grades. When our participants were asked to rate what they perceived to be motivators for participating in online discussions, the participants' most common motivations were associated with extrinsic motivators, especially earning an acceptable participation grade (98.82\%) or getting through the course (97.62\%). A desire to increase their content knowledge trailed behind at $87.07 \%$. For the participants, grades were more important than their intrinsic desire to learn more about a content area. This tendency was also seen in previous findings by Yeh and Buskirk (2005), Pena-Shaft and Nicholls (2004), and An, Shin, and Lim (2009), in which students valued grades more than the opportunity to engage in carefree online class discussions with their classmates. Our participants' interest in grades and getting through the course may reflect that fact they were working professionals who may have been juggling family responsibilities on top of their online studies. Another potential explanation is that in contrast to self-study and reflection, universities are typically structured around the use of grades, degrees, and certificates, which reward extrinsic motivation. Ryan and Deci (2000) noted that external rewards such as grades can undermine a person's internal motivation. For example, the completion rate for the voluntary online courses using the Massive Open Online Courses (MOOC) format is less than $7 \%$ (Hartnett, 2016), and the completion rate for one Massive Open Online Course was less than 3\% (Bonk \& Khoo, 2014).

With regard to their other reasons for participating in online discussions, the participants expressed a stronger interest in helping classmates (72.62\%) or having open interactions (61.45\%) than in forming friendships with classmates (29.76\%). The importance of helping others is an important component in service occupations such as teaching, and the participant's desire to have open interactions with their peers supports Vygotsky's premise that individuals make sense of information through their interactions with other people (Brooks \& Bippus, 2012). However, busy work schedules and possible family obligations may have left the participants feeling that the feasibility of forming friendships was limited.

Díaz, Swan, Ice, and Kupczynski (2010) found that learners viewed social presence as the least important component in the Community of Inquiry model. To promote a feeling of connection to other classmates, the instructor may divide the class into small groups at the beginning of the semester. To help build a sense 
of rapport, the instructor can provide a typed or video introduction to students (Bonk \& Khoo, 2014). Then, learners can post a typed introduction or a video introduction for members of their small group and the class. During the course, the instructor can discuss educational theories with examples and then have the learners work in their small groups to create their own examples based on their grade level and content area. At other times, the learners can work in their group to compare or contrast theories and provide their judgment about the theories. Small group discussions can be supplemented with periodic visits from the course instructor, who shares examples from different small groups with the entire class. Through this process, the instructor can determine the learners' understanding of the course content and learners can develop rapport with fellow small group members in a focused manner. Ryan and Deci (2000) noted that developing a sense of connection to a group can facilitate individuals' internal motivation, their willingness to engage in externally motivated behaviours, and their willingness to accept the classroom's values.

Another alternative is to create a virtual space where class members can interact outside of their course assignments such as an optional private online course blog, café, or wiki where students can share social information such as an upcoming conference or job opening (Bonk \& Khoo, 2014). Bonk and Khoo (2014) argue that providing learners with options within a course can support the learners' need for autonomy and can promote their passion and commitment to learn the course content.

Intrinsic and extrinsic motivators sometimes interact with each other to promote or undermine intrinsic motivations in social contexts (Ryan \& Deci, 2000). We ran a correlation coefficient analysis to determine whether there was a correlation between intrinsic and extrinsic motivators associated with cognitive and social presences, but the results yielded no statistically significant correlation between the intrinsic and extrinsic motivators. However, we only included two extrinsic and four intrinsic factors in this study. Further studies are necessary to investigate the relationship between these factors by integrating a larger number of potential intrinsic and extrinsic motivating factors.

\section{Teaching Presence}

Next, we investigated students' perceptions of engaging factors associated with grouping, discussion facilitation, and the types of questions that motivate participation in online discussions.

Discussion grouping. In our study, small-group discussion was more motivating to the teacher candidates as they participated in online discussions. About $81 \%$ of participants preferred discussions with a small group than either a whole group discussion (38.83\%) or think/pair/share discussion (37.21\%). The small group format can facilitate rapport among group members during small group discussion. In contrast, with whole group discussion in a large, online class, students can become frustrated because the amount of time and effort that it takes to read comments and type responses online can be much more than face to face conversations (An \& Frick, 2006). The Think, Pair, and Share approach allows students to interact with a fellow classmate, but if the instructor does not assign each student a partner, trying to locate a partner in an online class of over 350 people can be a challenge.

Discussion facilitation. While research in previous studies showed mixed results (An, Shin, \& Lim, 2009; Dykman \& Davis, 2008; Gilmore \& Warren, 2007; Mazzolini \& Maddison, 2007; Rollag, 2010; Xie, DeBacker, \& Ferguson, 2006; Zhu, 2006), in our study, participants preferred the instructor to fill the 
facilitator's role of providing answers to content- or task-related questions. Specifically, $67.06 \%$ of the participants desired to have the instructor only focus on answering their questions about the course content or clarifying class assignments. To address this need, the instructor can give the learners the option of sending the instructor an e-mail or posting their question to the course's private class discussion board or blog. Similarly, Hew and Cheung (2012) noted that university students preferred to have an instructor facilitate an online discussion in the role of an expert to answer their questions if they are confused about some aspect of the course or having trouble understanding the class content. Likewise, in Hartnett's (2016) case study with undergraduate teacher candidates taking online classes, the participants emphasized the need to obtain clear assignment directions and answers from their instructor or lecturer to their questions about the assignments. Ryan and Deci (2000) argue that helping an individual to understand the task and to be competent at the task can facilitate an individual's internal motivation and external selfdetermination.

In contrast to previous studies in which the class preferred to have a classmate lead the online discussion (Rourke \& Anderson, 2002; Seo, 2007; Tagg, 1994), in our study, the participants showed a low level of interest in having themselves or a class member facilitate the online discussion (15.29\%). They preferred having Teaching Assistants (62.35\%) or the instructor do so (58.83\%). Being an online discussion facilitator can involve a very large commitment of time with little downtime (Dykman \& Davis, 2008; Meyer \& McNeal, 2011; Rollag, 2010; Rourke \& Anderson, 2002; Seo, 2007). Work commitments coupled with potential family commitments could help explain the participants' lack of interest in facilitating online class discussions.

Discussion questions. To evaluate discussion questions, the survey included questions on the different levels of Bloom's taxonomy to determine what type of questions would motivate respondents to participate in online discussions. Bloom's taxonomy is a commonly used framework for educators as they develop questions, and there are six levels of questioning: facts/knowledge, comprehension, application, analysis, synthesis, and evaluation/judgment (Bloom, Engelhart, Furst, Hill, \& Krathwohl, 1956). Meyer (2014) asserted that having an online discussion without a goal or objective can result in poor participant engagement. In addition, Coole and Watts (2009) found that when the instructor's expectations about the online discussion are unclear or do not have specific objectives, teacher candidates' engagement in online discussions is primarily limited to reading their fellow classmates' posts and asking the instructor questions about the class assignments. Consequently, to build a strong online learning community through discussion, clear expectations and objectives for each discussion are strongly recommended (Freeman, n.d.).

All participants in our study were in-service educators. We found that $89.54 \%$ of them had the highest preference for questions associated with application in online discussion. As practicing educators, they tended to prefer application questions that allowed them to connect course contents and practice. Relating contents to students' personal interests is a key to making their learning meaningful and relevant, which can increase their external motivation to participate in discussions (Skinner, 2009).

While Maurino (2006-2007) found that higher level thinking during online class discussions was uncommon, our study also showed that $78.83 \%$ of the participants were interested in analysis and $78.82 \%$ were interested in synthesis. This is a promising result since these are considered higher-order thinking 
questions in Bloom's taxonomy. If participants can practice analyzing and synthesizing the contents or concepts learned from the course, they would become better equipped educators who have the ability to engage their students in higher-order thinking practices. By carefully scaffolding student learning that uses appropriate questioning, learners can progress from a basic understanding to a more complex grasp of the course content (Zhu, 2006) and can enhance their own higher-order thinking skills.

\section{Limitations and Future Research}

Our study focused on working professionals in the field of education, but these results cannot be generalized to all working professionals or all graduate students. Although our participants were working full time in educational settings, other online classes may include students who are not employed and who are full time students. Future research could evaluate different structures for online discussions that would better meet the educational needs of working professionals and non-employed full time students.

Another variable of consideration is content area. Our population was professionals in the field of education, and our participants had self-selected to take course work in this content area. Their self-selection may have impacted our results. Future research could expand our study to different content areas in different regions of the United States or in other countries.

Additional variables for future research include gender and ethnicity variance. In our study, the population was primarily Caucasian female educators. Males and individuals with other races or ethnicities could have a different point of view about online discussions. Future studies could expand this study to examine their views about online education and online discussions.

\section{Conclusion}

Displeasure about online discussion has been a domestic and global issue (Lee, 2014; Gerbic, 2006; Hew \& Cheung, 2012; Pisutova-Gerber \& Malovicova, 2009), so we went directly to the teacher candidates to hear their thoughts about ways to improve discussion in online classes. In terms of intrinsic versus extrinsic motivation, their main motivation to participate in online class discussions was extrinsic (85.88\%) so that they could earn an acceptable participation grade. With regards to discussion grouping formats, they strongly preferred (81\%) small group discussions. With respect to discussion facilitation, they focused on a pragmatic need to have the instructor to answer their questions about course assignments (67.06\%). Next, when asked about discussion question types based on Bloom's taxonomy, their strongest preference reflected a pragmatic preference for application (89.54\%) questions. In our study, the participants emphasized the need for pragmatism in the design and implementation of the course. Our population was primarily female (87.21\%) between the ages of 26-55 years of age with the highest percentage (16.28\%) being 26 to 30 year olds. As working professionals who are balancing online graduate classes along with potential family responsibilities, their pragmatic approach to online discussion is understandable. To facilitate active participant engagement in online discussions, teacher education programs can recognize 
the contextual issues facing their teacher candidates and recognize the interplay between intrinsic/extrinsic motivation and Community of Inquiry when designing and implementing online courses. Our study only focused on teacher candidates from one university and does not reflect the entire population; however, busy, working professionals taking online coursework at other universities may also consider the course design elements discussed in the results of our study to be desirable. To support online students, other universities may also choose to explore the needs of their online population with respect to online course discussion.

To further support working adults within large online classes, instructors may choose to focus on quality rather than quantity. For example, instructors may require fewer online discussions, and when they take place, instead of having an open discussion, they can be focused on applying a course concept to the classroom. Next, because online classes designed for working professionals may include some teacher candidates who desire enrichment opportunities, the instructor can create optional enrichment online discussions where in-service teachers can discuss alternative course topics online in depth. By collaborating with online learners, instructors can use data-driven decision making to transform online discussion from being the least desirable component of online courses to being a relevant instructional medium that better meets the needs of twenty-first-century learners.

\section{References}

Allen, I. E., \& Seaman, J. (2013). Changing course: Ten years of tracking online education in the United States. Boston, MA: Babson Survey Research Group and Quahog Research Group, LLC.

Ambient Insight Research. (2009). The U.S. market for self-paced eLearning products and services: 201O2015 Forecast and analysis. Retrieved from http://www.ambientinsight.com/Resources/Documents/AmbientInsight_US_20082013_LearningTechnologyMarket_ExecutiveOverview.pdf

An, Y. -J., \& Frick, T. (2006). Student perceptions of asynchronous computer-mediated communication in face-to-face courses. Journal of Computer-Mediated Communication, 11(2), 485-499. doi:10.1111/j.1083-6101.2006.00023.x

An, H., Shin, S., \& Lim, K. (2009). The effects of different instructor facilitation approaches on students' interactions during asynchronous online discussions. Computers \& Education, 53, 749-760. doi:10.1016/j.compedu.2009.04.015

Arbaugh, J. B., Cleveland-Innes, M., Diaz, S. R., Garrison, D. R., Ice, P., Richardson, J. C., \& Swan, K. P. (2008). Developing a community of inquiry instrument: Testing a measure of the community of inquiry framework using a multi-institutional sample. Internet and Higher Education, 11(3-4), 133-136. doi:10.1016/j.iheduc.2008.06.003 
Barkley, E. F. (2010). Student engagement techniques: A handbookfor college faculty. San Francisco, CA: Jossey-Bass.

Berk, L. E., \& Winsler, A. (1995). Scaffolding children's learning. Washington DC: National Association for the Education of Young Children.

Bloom, B., Engelhart, M. Furst, E., Hill, W., \& Krathwohl, D. (1956). Taxonomy of educational objectives: The classification of educational goals. Handbook I: Cognitive domain. New York, NY: David McKay Co Inc.

Bonk, C. J., \& Khoo, E. (2014). Adding some tech-variety. Retrieved from http://tec-variety.com/TECVariety_eBook_5-4.pdf

Brooks, C. F., \& Bippus, A. M. (2012). Underscoring the social nature of classrooms by examining the amount of virtual talk across online and blended college courses. European Journal of Open, Distance, and E-Learning, 1. Retrieved from http://www.eurodl.org/?p=archives\&year=2012\&halfyear=1

Christensen, C., M., Horn, M. B., Caldera, L., \& Soares, L. (2011). Disrupting college: How disruptive innovation can deliver quality and affordability to postsecondary education. Retrieved from http://www.innosightinstitute.org/innosight/wpcontent/uploads/2011/o2/future_of_higher_ed-2.3.pdf

Coole, H., \& Watts, M. (2009). Communal e-learning styles in the online classroom. Research in Education, 82, 13-27.

Correia, A. P., \& Davis, N. E. (2007). The design of collaboration in the virtual classroom. Retrieved from http://www.aect.org/pdf/proceedings07/2007I/07_12.pdf

Deci, E. L., Cascio, W. F., \& Krusell, J. (1975). Cognitive evaluation theory and some comments on the Calder and Staw critique. Journal of Personality and Social Psychology, 31(2), 81-85.

Deci, E. L., \& Ryan, R. M. (1985). Intrinsic motivation and self-determination in human behavior. New York, NY: Plenum.

Díaz, S. R., Swan, K., Ice, P., \& Kupczynski, L. (2010). Student rating of the importance of survey items, multiplicative factor analysis, and the validity of the community of inquiry survey. Internet and Higher Education, 13, 22-30. doi:10.1016/j.iheduc.2009.11.004

$\mathrm{Du}$, J., \& Xu, J. (2010). The quality of online discussion reported by graduate students. Quarterly Review of Distance Education, 11, 13-24.

Dykman, C., \& Davis, C. (2008). Online education forum - Part three: A quality online educational experience. Journal of Information Systems Education, 19(3), 281-289. 
Fisher, K. (2010). Online student engagement: CCSSE finds enrollment status and online experience are key. Community College Week, 22(20), 7.

Freeman, J. (n.d.). Using discussion in online courses: The importance of interactivity. Retrieved from https://academics.utep.edu/Portals/844/nofo/Using\%20Discussions\%20in\%20Online\%20Cour ses.pdf

Fung, Y. Y. H. (2004). Collaborative online learning: Interaction patterns and limiting factors. Open Learning, 19(2), 135-149. doi: 10.1080/0268051042000224743

Garrison, D. R. (2007). Online community of inquiry review: Social, cognitive, and teaching presence issues. Journal of Asynchronous Learning Networks, 11(1), 61-72.

Garrison, D. R., Anderson, T., \& Archer, W. (2000). Critical inquiry in a text-based environment: Computer conferencing in higher education. The Internet and Higher Education, 2(2-3), 87-105.

Garrison, D. R., Anderson, T., \& Archer, W. (2001). Critical thinking, cognitive presence and computer conferencing in distance education. The American Journal of Distance Education, 15(1), 7-23. doi: 10.1080/08923640109527071

Gay, L. R., Mills, G. E., \& Airasian, P. (2009). Educational research: Competencies for analysis and application. Upper Saddle River, NJ: Pearson.

Gerbic, P. (2006). To post or not to post. Undergraduate student perceptions about participating in online discussions. In Who's learning? Whose technology? Proceedings Ascilite Sydney 2006. Retrieved from http://www.ascilite.org.au/conferences/sydneyo6/proceeding/pdf_papers/p124.pdf

Gilmore, S., \& Warren, S. (2007). Emotion online: Experiences of teaching in a virtual learning environment. Human Relations, 6o(4), 581-608. doi: 10.1177/0018726707078351

Hall, R. A. (2015). Critical thinking in online discussion boards: Transforming an anomaly. The Delta Kappa Gamma Bulletin International Journal for Professional Educators, 81(3), 21-43.

Hammond, M. (1999). Issues associated with participation in online forums - the case of the communicative learner. Education and Information Technologies, 4(4), 353-367.

Hartnett, M. (2016). Motivation in online education. Singapore: Springer Science+Business Media. doi: 10.1007/987-981-10-0700-2

Hew, K. F., \& Cheung, W. S. (2010a). Possible factors influencing Asian students' degree of participation in peer-facilitated online discussion forums: A case study. Asia Pacific Journal of Education, 3o(1), 85-104. doi:10.1080/02188790903503619

Hew, K. F., \& Cheung, W. S. (2010b). The relationship between group size and advanced level knowledge construction in asynchronous online discussion environments. In C. H. Steel, M. J. Keppell, P. 
Gerbic, \& S. Housego (Eds.). Curriculum, technology and transformation for an unknown future. Proceedings Ascilite Sydney 2010 (pp. 428-432). Sydney: Ascilite.

Hew, K. F., \& Cheung, W. S. (2012). Student participation in online discussions: Challenges, solutions, and future research. New York, NY: Springer.

Jeong, A., \& Frasier, S. (2008). How day of posting affects growth patterns in asynchronous discussion threads in computer-supported collaborative argumentation. British Journal of Educational Technology, 39(5), 875-887. doi:10.1111/j.1467-8535.2007.00789.x

Lee, J. (2014). An exploratory study of effective online learning: Assessing satisfaction levels of graduate students of mathematics education associated with human and design factors of an online course. The International Review of Research in Open and Distributed Learning . 15(1), 111-132.

Leedy, P. D., \& Ormrod, J. E. (2016). Practical research: Planning and design. Boston, MA: Pearson.

Mandigo, J. L., \& Holt, N. L. (1990). Putting theory into practice: How cognitive evaluation theory can help us motivate children in physical activity environments. Journal of Physical Education, Recreation \& Dance, 71(1), 44-49.

Maurino, P. S. M. (2006-2007). Looking for critical thinking in online threaded discussions. Journal of Educational Technology Systems, 35(3), 241-260.

Mazzolini, M., \& Maddison, S. (2007). When to jump in: The role of the instructor in online discussion forums. Computers \& Education, 49, 193-213. doi:10.1016/j.compedu.2005.06.011

Meyer, K. A. (2014). Student engagement online: What works and why. San Francisco, CA: Whiley Subscription Services.

Meyer, K. A., \& McNeal, L. (2011). How online faculty improve student learning productivity. Journal of Asynchronous Learning Networks, 15(3), 37-53.

Nagel, D. (2010). The future of e-learning is more growth. Campus Technology. Retrieved from https://thejournal.com/articles/2010/03/03/the-future-of-e-learning-is-more-growth.aspx

Naughton, C., Smeed, J., \& Roder, J. (2011). Delimiting the prospect of openness: An examination of initial student approaches to e-learning. International Review of Research in Open and Distance Learning, 12(2), 103-121.

Nonnecke, B., \& Preece, J. (2000). Lurker demographics: Counting the silent. In T. Turner, G. Szwillus, M. Czerwinski, \& F. Paternò (Eds.), S. Pemberton (Associate Eds.), CHI 2000 Conference proceedings: Conference on human factors in computing systems (pp. 73-80). New York, NY: The Association for Computing Machinery, Inc. 
Norton, P., \& Hathaway, D. (2008). Exploring two teacher education online learning designs: A classroom of one or many? Journal of Research on Technology in Education, 4O(4), 475-495. doi:10.1080/15391523.2008.10782517

Osborne, J. (2015). What is rotating in exploratory factor analysis. Practical Assessment Research \& Evaluation, 20 (2), 1-7.

Pena-Shaft, J. B., \& Nicholls, C. (2004). Analyzing student interactions and meaning construction in computer bulletin board discussions. Computers \& Education, 32(3), 221-238. doi:10.1016/j.compedu.2003.08.003

Pisutova-Gerber, K., \& Malovicova, J. (2009). Critical and higher order thinking in online threaded discussions in the Slovak context. International Review of Research in Open and Distance Learning, $10(1), 1-15$.

Qui, M., Hewitt, J., \& Brett, C. (2014). Influence of group configuration on online discourse writing. Computer \& Education, 71, 289-302. doi: 10.1016/j.compedu.2013.09.010

Rettig, M. (2013). Online postings of teacher education candidates completing student teaching: What do they talk about? Linking Research \& Practice to Improve Learning, 57(4), 40-45.

Rietveld, T. \& Van Hout, R. (1993). Statistical techniques for the study of language and language behavior. Berlin - New York, NY: Mouton de Gruyter.

Rollag, K., (2010). Teaching business case studies online through discussion boards: Strategies and best practices. Journal of Management Education, 34(4), 499-526. doi: 10.1177/1052562910368940

Romero, M., \& Barberà, E. (2011). Quality of learners' time and learning performance beyond quantitative time-on-task. The International Review of Research in Open and Distance Learning, 12(5), 126137.

Rourke, L., \& Anderson, T. (2002). Using peer teams to lead online discussion. Journal of Interactive Media in Education, 1. Retrieved from http://www-jime.open.ac.uk/article/view/37/

Russell, M., Kleiman, G., Carey, R., \& Douglas, J. (2009). Comparing self-paced and cohort-based online courses for teachers. Journal of Research on Technology in Education, 41(4), 443-466.

Ryan, R, M., \& Deci, E. L. (2000). Intrinsic and extrinsic motivations: Classic definitions and new directions. Contemporary Educational Psychology, 25, 54-67. doi:10.1006/ceps.1999.1020

Schellens, T., \& Valcke, M. (2006). Fostering knowledge construction in university students through asynchronous discussion groups. Computers \& Education, 46, 349-370.

doi:10.1016/j.compedu.2004.07.010 
Seo, K. K. (2007). Utilizing peer moderating in online discussion: Addressing the controversy between teacher moderation and nonmoderation. The American Journal of Distance Education, 21(1), 2136. doi:10.1080/08923640701298688

Shea, P., \& Bidjerano, T. (2009). Community of inquiry as a theoretical framework to foster "epistemic engagement" and "cognitive presence" in online education. Computers \& Education, 52, 543553. doi:10.1016/j.compedu.2008.10.007

Skinner, E. (2009). Using community development theory to improve teacher engagement in online discussion: A case study. ALT-J, Research in Learning Technology, 17(2), 89-100. doi: 10.1080/09687760902951599

Stein, D. S., Wanstreet, C. E., Slagle, P., Trinko, L. A., \& Lutz, M. (2013). From "hello" to higher-order thinking: The effect of coaching and feedback on online chats. Internet and Higher-Education, 16, 78-84. doi:10.1016/j.iheduc.2012.03.001

Sweet, M., \& Michaelson, L. (2012). Critical thinking and engagement: Creating cognitive apprenticeships with team-based learning. In M. Sweet \& L. Michaelson (Eds.), Team based learning in the social sciences and humanities: Group work that works to generate critical thinking and engagement (pp. 5-32). Sterling, VA: Stylus Publishing.

Tagg, A. C. (1994). Leadership from within: Student moderation of computer conferences. American Journal of Distance Education, 8(3), 40-50. doi:10.1080/08923649409526865

Umbach, P. D., \& Wawrzynski, M. R. (2005). Faculty do matter: The role of college faculty in student learning and engagement. Research in Higher Education, 46(2), 153-184. doi: 10.1 007/s 111 62004- 1 598- 1

Winograd, D. (2000). The effects of training moderation in online asynchronous distance learning. In M.Crawford \& M. Simonson (Eds.), Annual proceedings of selected research and development papers presented at the National Convention of the Association for Educational Communications and Technology. Volumes 1 and 2 (pp. 462-470). Denver, CO: National Convention of the Association for Educational Communications and Technology.

Xie, K., DeBacker, T. K., \& Ferguson, C. (2006). Extending the traditional classroom through online discussion: The role of student motivation. Journal of Educational Computing Research, 34(1), 67-89.

Yeh, H. T., \& Buskirk, E. V. (2005). An instructor's methods of facilitating students' participation in asynchronous online discussion. In C. Crawford, D. A. Willis, R. Carlsen, I. Gobson, K. McFerin, J. Price, \& R. Weber (Eds.), Proceedings of Society for Information Technology and Teacher Education International Conference 2005 (pp. 682-688). Chesapeake, VA: AACE. 
Investigating Students' Perceptions of Motivating Factors of Online Class Discussions

Lee and Martin

Zhu, E. (2006). Interaction and cognitive engagement: An analysis of four asynchronous online discussions. Instructional Strategies, 34(6), 451-480. doi: 10.1007/s11251-006-0004-o 


\section{Appendix}

\section{Survey}

Note. 5 point-Likert scale ( $5=$ Strongly Agree; $4=$ Agree; $3=$ Neutral; $2=$ Disagree ; and $1=$ Strongly Disagree) was provided on each item from 5-6.

1. What is your gender?

- Female

- Male

2. What is your racial/ethnic background?

- American Indian/Alaska Native

- Asian

- Black/African American

- Hispanic

- Native Hawaiian or other Pacific Islander

- Other

- White

3. I am

- 18-25 years old

- 26-30 years old

- 31-35 years old

- 36-40 years old

- 41-45 years old

- 46-50 years old

- 51-55 year old

- 56-6o years old

- 61-65 years old

4. I am in the

- elementary education program

- middle level education program

- secondary education program.

- all level education(kindergarten through grade 12 program

5. In online classes, why do you participate in online discussions?

- earning an acceptable participation grade

- increasing knowledge of subject/materials

- building friendships

- helping classmates

- getting through the course

- practicing open interactions 
6. In online classes, what is your preference of grouping students during online discussions?

- The class divided into small groups.

- The class has a whole class discussion.

- Think/pair/share (Each student locates a partner, thinks about the class information, and the partners chat with each other. Then, the whole class has a discussion.)

7. In online classes, what is your preference during online discussions?

- The instructor facilitates the classes' online discussions.

- A teaching assistant/coach facilitates in the class' online discussions.

- A designated class member facilitates the classes' online discussions.

8. In online classes, during online discussions, what is your preference on the level of questioning?

- Threaded discussions based on the class readings emphasizing the knowledge level from Bloom's taxonomy (For example, facts about the class readings).

- Threaded discussion based on the class readings emphasizing the comprehension level from Bloom's taxonomy (For example, rephrasing information in your own words)

- Threaded discussion based on the class readings emphasizing the application level from Bloom's taxonomy (For example, applying class readings to other situations)

- Threaded discussion based on the class readings emphasizing the analysis level from Bloom's taxonomy (For example, comparing and/or contrasting class readings)

- Threaded discussion based on the class readings emphasizing the synthesis level from Bloom's taxonomy (For example, using the class content to create something novel such as a new way to teach math classes.)

- Threaded discussion based on the class readings emphasizing the judgment level from Bloom's taxonomy (For example, make a decision about class readings using criteria developed by you, the class, the course instructor, or other individuals.)

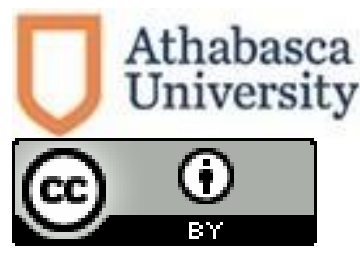

